\title{
A SCIENTIFIC SYMPOSIUM "ARTIFICIAL ORGANS TODAY: FROM IN VITRO ASSESSMENT TO HUMAN THERAPIES" ON THE OCCASION OF THE CELEBRATION OF THE 40TH ANNIVERSARY OF THE MACEDONIAN ACADEMY OF SCIENCES AND ARTS
}

\section{Momir H. Polenakovic}

Macedonian Academy of Sciences and Arts, North Macedonia

Corresponding author: Momir H. Polenakovic, Macedonian Academy of Sciences and Arts, Blvd. Krste Misirkov 2, Skopje, N. Macedonia, e-mail: momir@manu.edu.mk

\section{ABSTRACT}

On the occasion of the celebration of the 40th anniversary of the Macedonian Academy of Sciences and Arts (MASA) the Macedonian Society of Nephrology, Dialysis, Transplantation and Artificial Organs (MSNDTAO) organized a one day symposium titled: "Artificial Organs Today: From in vitro assessment to human therapies", on September 28, 2007 at the Macedonian Academy of Sciences and Arts. The following sessions were held: Artificial Organs in Front of the Ageing Populations; System Requirements for Artificial Organ Technology; Tools for Artificial Organ Technology; Extracorporeal Blood Circuits in Organ Replacement Therapies; Treatment Options for Blood Purification Therapies. Presentation were delivered by: Horst Klinkmann, Germany; Jörg Vienken, Germany; Jens Hartmann, Austria; Udo Losert, Austria; Jan Wojcicki, Poland; Helmut Mann and Siegfried Stiller, Germany; Beat Walpoth, Switzerland; Juan F. del Cañizo, Spain; Borce Georgievski, Macedonia; Bernd Stegmayr, Sweden; Momir Polenakovic, Macedonia; Petar Kes, Croatia; Aleksandar Sikole, Macedonia; Wolfgang Ramlow, Germany; Dieter Falkenhagen, Austria. These meetings are significant for the application and development of the artificial organs in patients.

Keywords: artificial organs, biomaterials, dialysis, heart support systems, stem cells, apheresis

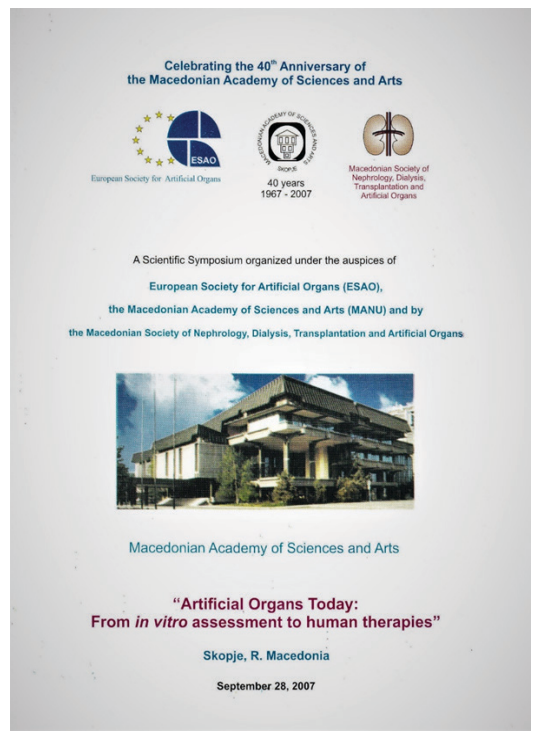


On the occasion of the celebration of the 40th anniversary of the Macedonian Academy of Sciences and Arts (MASA) the Macedonian Society of Nephrology, Dialysis, Transplantation and Artificial Organs (MSNDTAO) organized a one day symposium titled: "Artificial Organs Today: From in vitro assessment to human therapies", on September 28, 2007 at the Macedonian Academy of Sciences and Arts. The symposium was organized under the auspices of the European Society for Artificial Organs (ESAO), MASA and MSNDTAO. Main sponsor of the meeting was Fresenius Medical Care, a renowned producer of artificial kidneys, and co-sponsors were Gambro, Hoffman-La Roche, Janssen-Cilag and Alkaloid.

Acad. Cvetan Grozdanov, President of MASA welcomed the numerous participants in the meeting and he wished them a successful application of the artificial organs in R. Macedonian and beyond.

The following presentation was delivered in Session I (Artificial Organs in Front of the Ageing Populations): Horst Klinkmann (Rostock, Germany) Health is wealth, is wealth health?

The following presentations were delivered in Session II (System Requirements for Artificial Organ Technology): Jörg Vienken (Bad Homburg, Germany) Testing biomaterials for the application in artificial organs: impact of donor and patient properties and procedures; Jens Hartmann (Krems, Austria) Anticoagulation in combined membrane/ adsorption systems; Udo Losert (Vienna, Austria) Animal models for artificial organs.

The following presentations were delivered in Session III (Tools for Artificial Organ Technology): Jan Wojcicki (Warsaw, Poland) Monitoring of the patient's metabolic state by microdialysis techniques; Helmut Mann and Siegfried Stiller (Aachen, Germany) Modeling dialytic therapies: theoretics and practices; Beat Walpoth (Geneva, Switzerland) From vascular prostheses to tissue- engineered vascular grafts; Juan F. del Cañizo (Madrid, Spain) Heart support systems: from the idea to the clinical practice; Borce Georgievski (Skopje, Macedonia) Stem cells - approaches to new therapies.

The following presentations were delivered in Session IV (Extracorporeal blood circuits in organ replacement therapies): Bernd Stegmayr (Umea, Sweden) Peritoneal dialysis as a valuable tool for blood purification; Momir Polenakovic (Skopje, Macedonia) Dialysis and Apheresis in Macedonia: A success story; Petar Kes (Zagreb, Croatia) New experiences with the therapy of Acute Renal Failure.

The following presentations were delivered in Session V (Treatment Options for Blood Purification Therapies): Aleksandar Sikole (Skopje, Macedonia) New approaches in the therapy of Hepatitis C (HCV) in dialysis patients; Wolfgang Ramlow (Rostock, Germany) New applications in Therapeutic Apheresis; Dieter Falkenhagen (Krems, Austria) Sepsis therapy through adsorber systems.

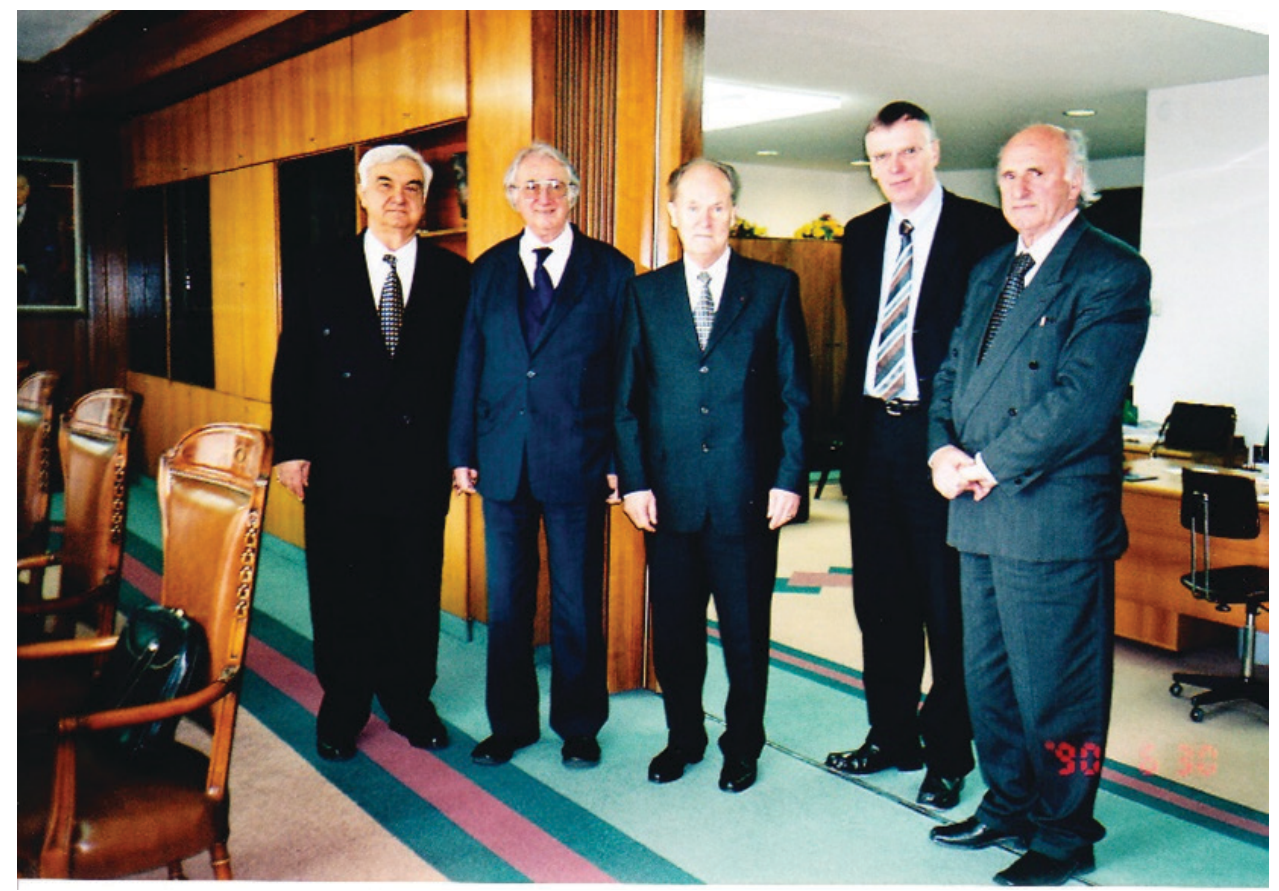

From left to right: Momir Polenakovic, Mateja Matevski, Horst Klinkmann, Joerg Vienken, Georgi Stardelov 
The presentations were followed by discussion and guidelines about the future actions in the development and application of the artificial organs.

It was concluded that symposium was successful, and that similar symposia are to be organized in future. The participants express their appreciation to the members of MASA for the scientific support, organization and wished for many years of successful work.

Acknowledgement to Goce Aleksoskifor the technical assistance.

The paper is part of the project "History of Nephrology in North Macedonia", funded by the

Macedonian Academy of Sciences and Arts.

Резиме

\begin{abstract}
НАУЧЕН СИМПОЗИУМ: ARTIFICIAL ORGANS TODAY: FROM IN VITRO ASSESSMENT TO HUMAN THERAPIES ПО ПОВОД ОДБЕЛЕЖУВАЊЕТО НА 40-ГОДИШНИНАТА ОД ПОСТОЕЊЕТО НА МАКЕДОНСКАТА АКАДЕМИЈА НА НАУКИТЕ И УМЕТНОСТИТЕ (МАНУ)
\end{abstract}

\title{
Момир Х. Поленаковиќ
}

Македонска академија на науките и уметностите, Скопје, РС Македонија

По повод одбележувањето на 40-годишнината од постоењето на Македонската академија на науките и уметностите (МАНУ), Македонското друштво за нефрологија, дијализа и трансплантација и вештачки органи (МЗНДТВО) организираше еднодневен симпозиум со наслов Artificial Organs Today: From in vitro assessment to human therapies, на 28.9.2007 година во Македонската академија на науките и уметностите. Беа одржани следниве сесии: Artificial Organs in front of the ageing populations; System Requirements for Artificial Organ Technology; Tools for Artificial Organ Technology; Extracorporeal blood circuits in organ replacement therapies; Treatment Options for Blood Purification Therapies. Предавањата ги одржаa: Хорст Клинкман, Германија; Јорг Финкен, Германија; Јенс Хартман, Австрија; Удо Лозерт, Австрија; Јан Војчицки, Полска; Хелмут Ман и Зигфрид Штилер, Германија; Беат Волпот, Швајцарија; Хуан Ф. Дел Кањизо, Шпанија; Борче Георгиевски, Македонија; Бернд Штегмаер, Шведска; Момир Поленаковиќ, Македонија; Петар Кес, Хрватска; Александар Шиколе, Македонија; Волфганг Рамлов, Германија; Дитер Фалкенхаген, Австрија. Ваквите состаноци се значајни за примена и развој на вештачките органи кај пациентите.

Клучни зборови: вештачки органи, биоматеријали, дијализа, системи за поддршка на срцето, матични клетки, афереза 